\title{
Natural and Human Disturbance in a Rookery of the California Sea Lion (Zalophus californianus californianus) in the Gulf of California, Mexico
}

\author{
Vanessa Labrada-Martagón ${ }^{1,2}$, David Aurioles-Gamboa ${ }^{1}$ and Sergio Francisco Martínez-Díaz ${ }^{1}$
}

\begin{abstract}
Los Islotes is the southernmost breeding site of the California sea lion (Zalophus californianus californianus) in the Northern Hemisphere and represents one of the principal tourist attractions for the city of La Paz, Mexico. The tourism has been growing without control and could be the cause of perturbation in the reproductive and haul-out patterns of the sea lion. The aim of the present study was to determine the effect of tourism activities on the behavior of sea lions, in order to help design regulations to assure better use and conservation of the site. The nature and intensity of tourism activity and sea lion behavior were determined based upon monthly sampling over a one-year period (May 2000-April 2001). Tourist activity was higher during autumn and winter, with visits by "panga" boats being the most numerous. A total of 112 disturbances were recorded, the majority of which being non-anthropogenic causes. A quarter of disturbances were triggered by human activity within $20 \mathrm{~m}$ of the rookery and with harassment reaction (animals going into the water) in $32 \%$ of the anthropogenic disturbances.

Principal component analysis (PCA) described the conditions under which disturbance was generated $(74 \%$ of the variation explained). Using three factors ( $47 \%$ of the total variation) the major contributing variables were month, tidal level, relative humidity, Beaufort number, total number of boats and number of powerboats and sailboats. In Los Islotes, the perturbation occurs mostly in autumn and winter coinciding with the highest frequency of tourism, large number of adult and subadult males and unfavorable environmental conditions for haul-out, such as high tide level and strong winds. The lowest number of disturbances occurred in summer, during the breeding season of the sea lion. Most of these, however, were caused by human activity.
\end{abstract}

Resumen: Los Islotes es el sitio más sureño de reproducción del lobo marino de California (Zalophus californianus californianus) en el Hemisferio Norte y representa la principal atracción turística de la ciudad de La Paz, México. El turismo ha crecido sin ningún control y puede ser causa de perturbación de los patrones reproductivos y de descanso del lobo marino. El objetivo de este trabajo fue determinar el efecto de la actividad turística en el comportamiento del lobo marino con la finalidad de generar información útil para el diseño de acciones que garanticen un mejor aprovechamiento y conservación del sitio. Se caracterizó y cuantificó la actividad turística y se realizó un seguimiento del comportamiento con muestreos mensuales a lo largo de un año (Mayo 2000 - Abril 2001). La actividad turística fue mayor los meses de otoño e invierno, siendo la embarcación con motor tipo "panga" la más numerosa. Se registraron 112 disturbios, la mayoría de los cuales fueron generados por causas no antropogénicas. Un cuarto de los disturbios fueron ocasionados por causas humanas generándose a distancias menores de $20 \mathrm{~m}$ de la lobera y ocasionando un efecto intenso (animales se van al agua) en el 32\% de los disturbios humanos.

Un análisis de componentes principales, ACP, describió las condiciones bajo las cuales se generó el disturbio (74\% varianza explicada). Usando tres factores ( $47 \%$ de la varianza total) las variables de mayor contribución fueron el mes, la marea, la humedad relativa, la categoría de Beaufort, el número total de embarcaciones y el número de embarcaciones con motor y de veleros. En Los Islotes el disturbio ocurrió principalmente en otoño e invierno cuando coincide la mayor afluencia turística, gran número de machos adultos y subadultos y condiciones ambientales desfavorables para el descanso en tierra de los animales, como marea alta y viento intenso. El menor número de disturbios se registró en verano, durante el periodo reproductivo del lobo marino, sin embargo la mayoría de estos disturbios fueron ocasionados por la actividad humana.

KEY wORDS: disturbance, tourism, tolerance, PCA, California sea lion, Zalophus californianus.

\section{Introduction}

As the southernmost breeding colony of California sea lions (Zalophus californianus californianus) in the Northern Hemisphere (Aurioles-Gamboa and Zavala-González, 1994), Los Islotes is of biological importance and one of the smallest breeding rookeries of the Gulf of California (Le Boeuf et al., 1983; Aurioles-Gamboa and ZavalaGonzález, 1994). Los Islotes rookery is also the California sea lion colony most visited by tourists in Mexico (SEMARNAP, 2000), due to its proximity to the city of La Paz, in Baja California Sur. A variety of vessels visit this site, contributing to making marine mammal tourism an important economic industry in the area (SEMARNAP, 2000; López-Espinosa, 2002).
The California sea lion was exploited for centuries along the Pacific coast of the United States and northern Mexico, originally for subsistence and later for commercial purposes (Zavala-Gonzalez and Mellink, 2000). In 1976, the capture of sea lions was banned by the Mexican Government and the species is currently protected (Aurioles-Gamboa et al., 1999), particularly because many of the rookeries are located in the Natural Protected Areas System. Presently, the major problems for the conservation of the California sea lion are habitat loss and disturbance caused by interactions with fisheries and tourism (Aurioles-Gamboa et al., 1999).

The charismatic nature of marine mammals and their proximity to the coast have allowed the development of the marine-mammal watching industry (i.e. Malcom

\footnotetext{
${ }^{1}$ Centro Interdisciplinario de Ciencias Marinas, Instituto Politécnico Nacional. Av. IPN s/n, Colonia Playa de Santa Rita, A. P. 592, La Paz, Baja California Sur, C.P. 23096, México.

${ }^{2}$ E-mail: vlabradam@ipn.mx; vlabrada@hotmail.com.
} 
and Lochbaum, 1999; Hoyt, 2001). During recent years, some companies in Mexico have begun to promote the eco-tourism of pinnipeds in haul-out and breeding areas (Aurioles-Gamboa et al., 1999). However, tourist activities can be an important source of disturbance for marine mammal populations (Kenyon, 1972; Allen, 1984; Suryan and Harvey, 1999; Bejder et al., 1999; Karamanlidis, 2000; Constantine, 2001; Henry and Hammill, 2001; Engelhard, 2002).

Several studies have documented the disturbance generated by human activities at pinniped colonies (Kenyon, 1972; Allen, 1984; Terhune, 1985; Jay et al., 1998; Suryan and Harvey, 1999; Henry and Hammill, 2001; Engelhard, 2002). Frequent disturbances have a greater effect on the breeding colonies, because they alter and interrupt haul-out and nursing patterns (Allen, 1984; Suryan and Harvey, 1999), and increase female vigilance and their energy expenditure (Suryan and Harvey, 1999). They can also alter the social order and mating behavior in polygamous and territorial species and can even result in mortality when it causes stampeding and pup abandonment (Richardson et al., 1995). Long-term effects of human disturbance may include a change from diurnal to nocturnal hauling out patterns (Paulbitsky, 1975, in Allen et al., 1984; Brasseur et al., 1996), abandonment of the breeding territory (Kenyon, 1972; Allen, 1991), changes in the original population distribution (Kenyon, 1972; Karamanlidis, 2000) and a subsequent decrease in both breeding success and population size (Johnson and Lavigne, 1999).

The impact of tourism activities on marine mammals in Mexico is unknown for most of the species (i.e. California sea lion, northern elephant seal, humpback whale and gray whale), making adequate management of tourism activities difficult. Understanding the effects of human disturbance is critical for effective management and conservation of species (Kerley et al., 2002). The aim of this study was to monitor the tourism activity and California sea lion behavior at Los Islotes rookery over an entire year. The objectives were: 1) to characterize and quantify the tourism activity in the area; 2) to characterize and quantify the disturbances according to the source (natural or anthropogenic) and the reaction of sea lions to the disturbance; and 3) to describe the conditions under which disturbances occur.

\section{Material and Methods}

Study Area. Los Islotes rookery is located on the southwest coast of the Gulf of California ( $\left.24^{\circ} 35^{\prime} \mathrm{N}, 110^{\circ} 23^{\prime} \mathrm{W}\right)$. It is part of the Espiritu Santo archipelago, located in La Paz Bay approximately $50 \mathrm{~km}$ north of La Paz, Baja California Sur, Mexico (Figure 1). The rookery is situated on two islands of $0.046 \mathrm{~km}^{2}$ total area, having a maximum height of $60 \mathrm{~m}$, with a rocky shoreline and a surrounding rocky reef. The mean annual air temperature is $23.6^{\circ} \mathrm{C}$ with a range of $11-44^{\circ} \mathrm{C}$ (SEMARNAT, 2000).
We divided the study area into six zones (Figure 1). Zones $\mathrm{A}$ and $\mathrm{B}$ are the main sea lion breeding sites. Zone A is the most protected from the impact of waves and about $30 \%$ of animals of the colony are found in this area during the breeding season. Zone $\mathrm{C}$ is mainly used as a haul-out site for males without territory but has been recently used for breeding (Hernández-Camacho, 2001). The remaining zones of the islands represent minor haul-out sites.

Observations. The field study was conducted from May 2000 to April 2001. With the exception of the total counts of sea lions, all the observations were carried out between 0830 and 1830 hours, during four days each randomly chosen month (exception for May=3 days, October=3 days, December $=2$ days, January $=2$ days, April=3 days) when tourists could be present. This was carried out from an elevated ( $3 \mathrm{~m}$ high) rocky lookout site located about $50 \mathrm{~m}$ away from the animals at the chosen study site of Zone A. Because of the location and the distance of the access to the lookout site, the researchers did not affect the behavior of the animals in Zone $\mathrm{A}$, as the rocks in the area did not allow the animals to see or hear the researchers when they arrived or stayed at the site. All the observations started 30min subsequent to the arrival of the researcher. Only two researchers at a time worked on the rookery to avoid movement and noise, staying in the lookout site during all the observation day with the exception of the census at midday.

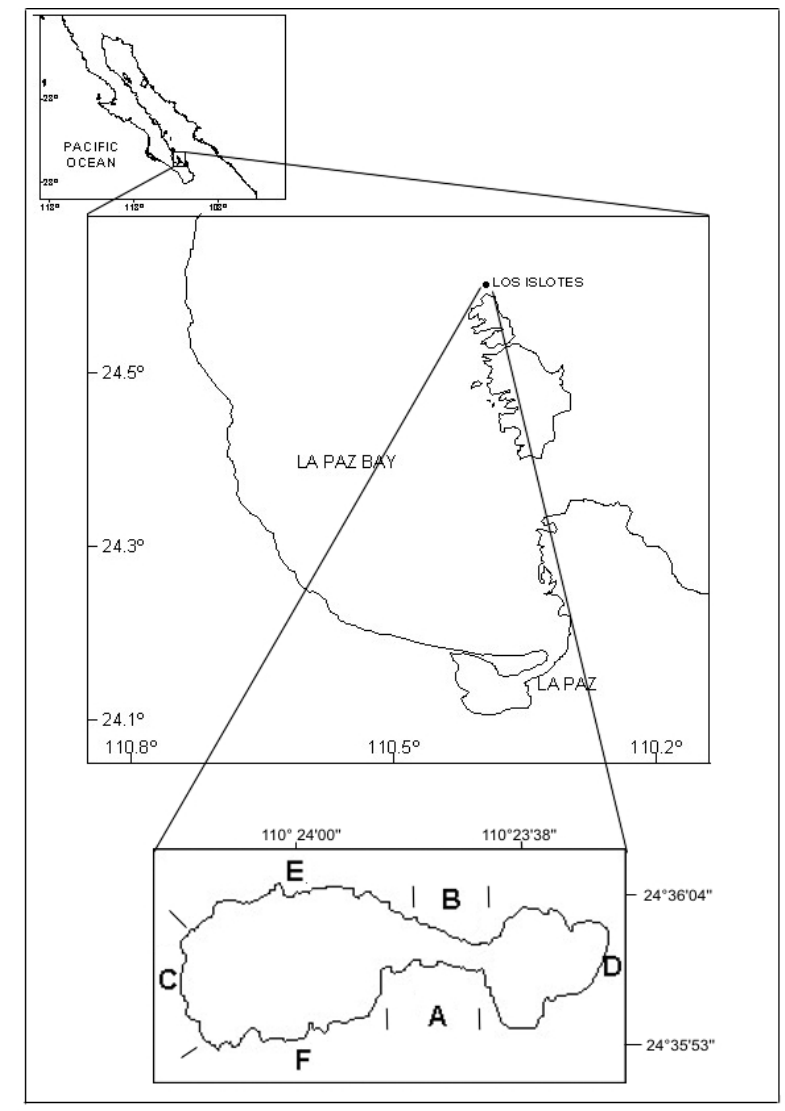

Figure 1. Map of La Paz Bay, Mexico, showing the Los Islotes study area. The six zones considered in this work are marked with letters. 
The total counts of sea lions were conducted every observation day, at midday, from an outboard motor launch. To estimate the total population size, Los Islotes were circumnavigated within $25-35 \mathrm{~m}$ of the shoreline and sea lions were classified by sex and age, as described by Aurioles-Gamboa et al. (1983) and Le Boeuf et al. (1983). Counts of sea lions were conducted in Zone A every 30 minutes from the rocky lookout site, it being our main target for tracking behavioral changes.

Air temperature $\left({ }^{\circ} \mathrm{C}\right)$, atmospheric pressure (mbar), relative humidity (\%), Beaufort sea state and tide level were also recorded every 30 minutes. The temperature and humidity were measured using a digital higrothermometer (Extech Instruments) (range between $-20^{\circ} \mathrm{C}$ and $50^{\circ} \mathrm{C} \pm 1^{\circ} \mathrm{C}$; and range between $25 \%$ and $95 \% \pm 6 \%$, respectively). The atmospheric pressure was measured with a mechanical barometer (Chelsea). Sea state was estimated using the Beaufort scale (Barnes-Svarney, 1995). Three tide levels were defined based on the degree of inundation of a reference platform at Zone A: a) Low tide, when the reference platform was free of water; $b$ ), Medium tide, when the reference platform was partially flooded and puddles were apparent; and c), High tide, when the reference platform was completely flooded.

Tourism activity at Los Islotes was also noted all day long when each boat arrived to the area. Numbers of all underway and anchored boats were recorded, as well as their arrival and departure times, type of boat, anchorage zone in Los Islotes and distance from the shoreline, number of people per boat and their activities. The distance of boats from shore was estimated using previously established visual references at known distances.

Observations of sea lions were made using $6 \times 30$ binoculars. Scan surveys (Altman, 1974) were conducted at $15 \mathrm{~min}$ intervals throughout the observation period. Each scan included the count of the sea lions in a focal group at Zone A, classified by sex and age, and their individual state of behavior (lying down, head up or suckling).

In this study disturbance was considered when a sudden change in the behavior of at least one sea lion in the focal group occurred. Date, hour and source of disturbance was recorded, the source of disturbance being classified as of human, natural or unknown sources. The three categories of sea lion reactions to disturbance described by Suryan and Harvey (1999) were used: 1) Detection: $\leq 1$ sea lion with head raised and oriented toward potential disturbance source; 2) Alarmed: $\leq 1$ sea lion moved from its resting place, but did not enter the water; 3) Harassed: $\leq 1$ sea lion entered the water.

Recovery after a disturbance was considered the moment when the altered animals returned to their initial behavior or when the original number of sea lions in the focal group returned to Zone A after the harassment ceased. If none of these occurred during the day of observation (the animals changes their state of behavior or did not come back), "no recovery" was recorded.

\section{Statistical analysis}

Population fluctuation during the year. The number of adult and subadult males in the colony was compared by month using analysis of variance (ANOVA). Normality and homogeneity of the variances were previously tested using the Kolmogorov-Smirnov and Bartlett tests, respectively (Adults: $D=0.1070, n=39, p>0.20 ; X^{2}=9.8$, d.f. $=11, p>0.5$; Subadults: $D=0.1722, n=39, p>0.2 ; X^{2}=12.7$, d.f. $=11, p>0.3$ ).

Suckling behavior. The number of suckling states observed were summed over the observation period each month and then divided by the mean number of females observed in the focal group that month and by the number of hours observed that month. An annual graph was prepared showing the resulting values of sucklings per female per hour.

Disturbance. When analyzing the disturbance data, the year was divided into three seasons according to the population dynamics of the California Sea lion: a) Summer (May-August) which includes the pupping and mating season (breeding season). During this period, the numbers of females and adult males present in the colony increase (García-Aguilar and Aurioles-Gamboa, 2003a), and is the time when the maximum number of animals are found on the breeding colonies (Le Boeuf et al., 1983); b) Autumn (September-December), is the period when adult males move out of the breeding colonies and the females remain in the vicinity of their breeding rookeries (Bartholomew, 1967). The rookeries are then dominated by adult females, pups, juveniles and some subadult males (Odell, 1975). In Los Islotes specifically, the number of subadult males begins to increase during these months (Aurioles-Gamboa et al., 1983); while c) Winter (JanuaryApril) is the period with the largest number of subadult males at Los Islotes, with a peak in January and decline from February to May (Aurioles-Gamboa et al., 1983).

Data concerning natural or human disturbances, as well as detection, alarmed or harassed reactions were grouped by season. Seasonal differences in the frequency of each category were analyzed using the Kruskall Wallis test. A Nemenyi test was used for significant K-W results Zar (1999).

Conditions of disturbance. Principal Component Analysis was used to evaluate the conditions under which disturbances occurred. The database of disturbances was arranged by date and hour of occurrence. The variables in the analysis were as follows: source of disturbance (NS= natural source; HS= human source), number of sea lions in Zone A, proportion of adult and subadult males (\%) in Zone A, temperature, tide level, Beaufort sea state, relative humidity, atmospheric pressure, total number of boats, number of sailboats at $0-10 \mathrm{~m}, 11-20 \mathrm{~m}$ and $21-30 \mathrm{~m}$ intervals, and number of powerboats at $0-10 \mathrm{~m}, 11-20 \mathrm{~m}$ and $21-30 \mathrm{~m}$ intervals. Missing data on relative humidity and atmospheric pressure were substituted by mean values.

The data were analyzed using the software Statistica for Windows version 6.0 (StatSoft Inc, 2001). 


\section{Results}

Population fluctuation during the year. In the year of study (May 2000-April 2001) the sea lion colony at Los Islotes showed two annual peaks of abundance, one during breeding season in summer and the second in winter. The first one is due to the increase in number of females, their pups and adult males that arrive at the colony to mate. The winter peak resulted mostly from the increase of subadult males and some adult males and females. Significant differences in the number of adult and subadult males were found when compared by months each category (ANOVA, Adult males: $F_{11,27}=2.95, p<0.05$; Subadult males: $\left.F_{11,27}=28.27, p<0.001\right)$. The number of adult males showed two peaks; the first occurred from May to July and the second from December to February, when subadult males are very abundant. In winter, the lowest number of adult males occurred in November (Figure 2). The number of subadult males started to increase in October, reaching its peak in March after which it decreased again. The lowest numbers of subadult males during the year were recorded in August and September (Figure 2).

Suckling behavior. The monthly variation in the number of suckling events per female per hour at Los Islotes is shown in Figure 3a. The tendency is of an increase from the breeding season to winter, and the highest rates of suckling for the year occurred during December and January. During breeding season, the highest number of suckling events occurred in June, which coincided with the peak of births in the colony (García-Aguilar and Aurioles-Gamboa, 2003a).

Tourism activity. Overall, the observation effort consisted of a total of 239 hours, conducted on 41 days of the year of study. During this observation time, more than 2700 visitors arrived at the site in 393 boats. At least one boat was observed in the proximity of the rookery every day, with the exception of 30 April 2001, when no boat arrived. Seven different types of boats were observed at Los Islotes. The "panga" type (outboard motor launch, 28ft $(8.5 \mathrm{~m})$ length) was seen every month and was the most frequent in the area (48\%), followed, in almost all months, by yachts (22\%), sailboats (10\%), large ships (160ft (49m) length) (4\%), and dinghies (2\%). Kayaks (10\%) and zodiacs $(4 \%)$ were noted at Los Islotes only during autumn and winter.

About half of the number of visits $(49 \%, n=192)$ occurred in October, November, February and March, with more than 2 boats arriving per hour (Figure 3b). During the day, $40 \%$ of all the boats arrived between 0900 and 1000 hours and $64 \%$ of them left the site between 1100 and 1500 hours. Most boats (60\%) stayed at the site from 30 minutes to 2 hours, although some boats stayed for as long as 6 hours. Eighty-one percent of all boats recorded were between 10 and $60 \mathrm{~m}$ from the shore with a peak $(27.5 \%)$ between 20 and $30 \mathrm{~m}$. The main anchorage areas were Zone A (33\% of all boats), Zone B (24\%) and Zone $\mathrm{D}(23 \%)$ and the most common recreational activities were: sea lion watching (30\%), snorkeling (27\%) and scuba diving (26\%). Other activities recorded were kayaking (9\%), fishing (5\%) and swimming (3\%).

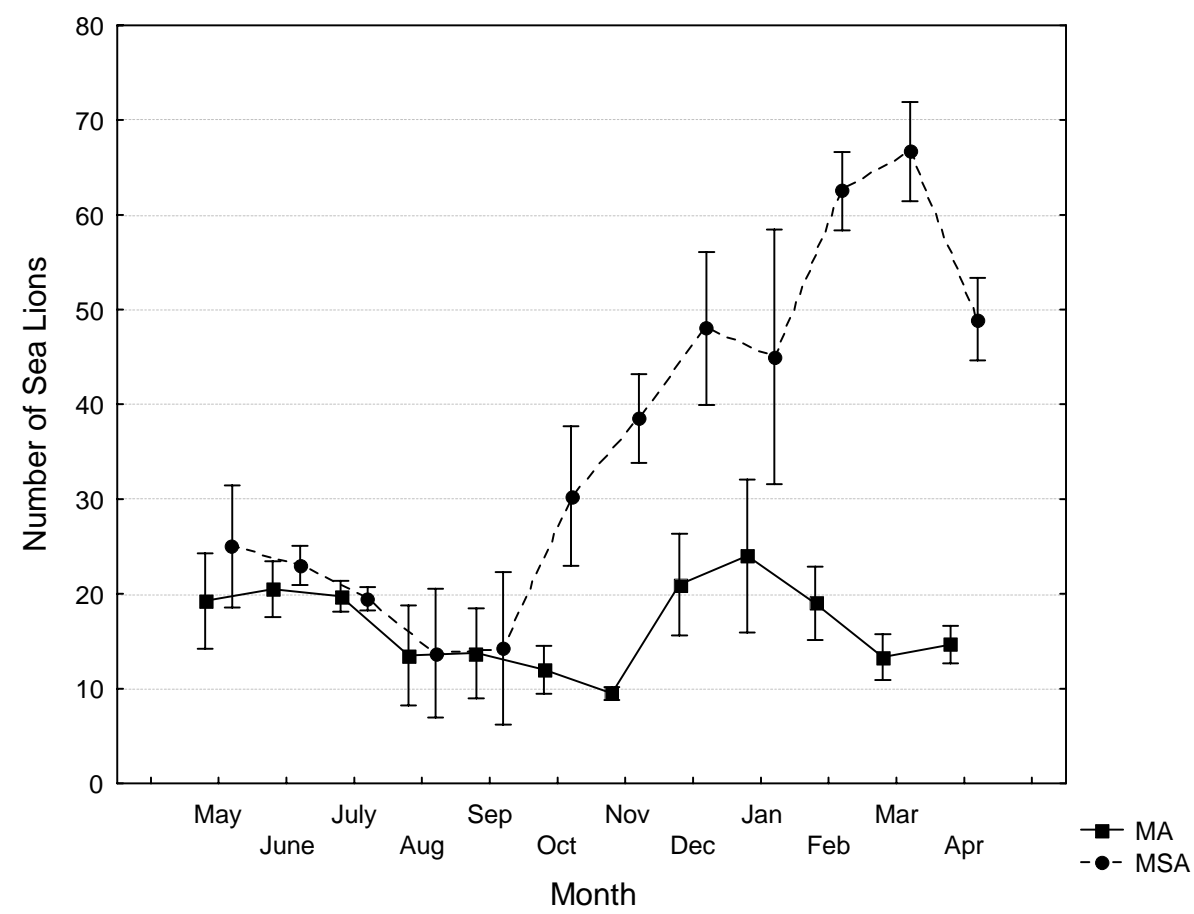

Figure 2. Monthly variation of adult males and subadult males at Los Islotes over the period May 2000-April 2001, showing the mean (squares) and standard deviation (lines). 

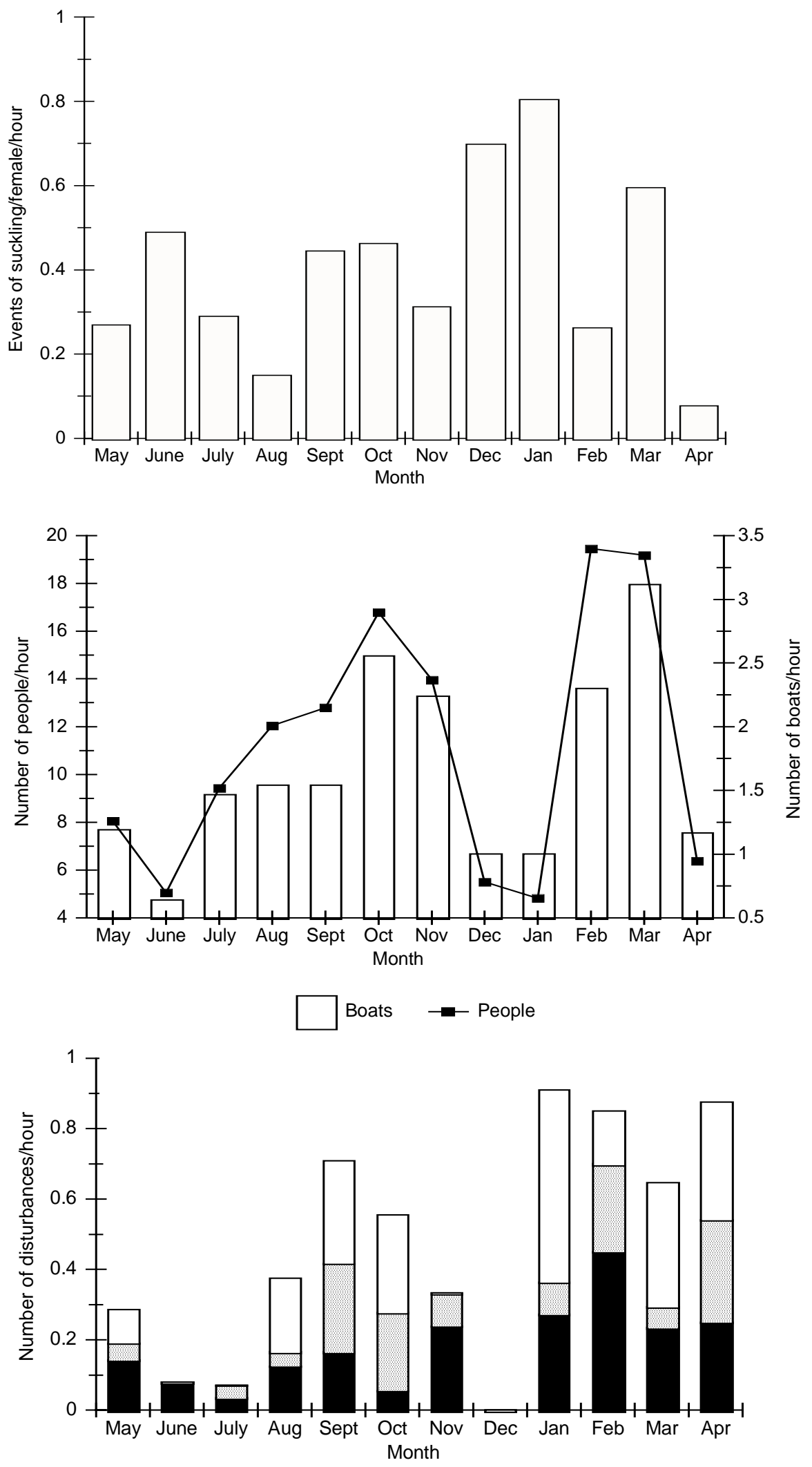

Detection $\square$ Alarmed $\square$ Harassed

Figure 3. (a) Monthly variation in the number of suckling events per female per hour at Los Islotes during May 2000-April 2001; (b) Monthly total number of boats and people per hour; (c) Monthly total number of disturbances by category of reaction per hour. 
Disturbance. Disturbance to the animals was generated on $70 \%$ of the survey days. A total of 112 disturbances were recorded throughout the year, except for December when no disturbances were observed. Natural disturbances were the most common and were caused mainly by adult and subadult males (Table 1). The highest number of human disturbances was generated by "panga" boats, due to their proximity to shore (in some cases less than $10 \mathrm{~m}$ ), and the noise associated with the people on it. Other possible human sources of disturbances were the noise of whooshing from scuba tanks, people's screams, the proximity of swimmers and divers and the approach of other types of boats (Table 1). Seventy-one percent of the human disturbances occurred when the sources were located less than $20 \mathrm{~m}$ from shore.

The lowest number of disturbances occurred during the breeding season; they increased during autumn and the greatest number occurred during winter (Figure 3c). The number of natural disturbances were significantly different between seasons $\left(\mathrm{H}_{4,4,4}=6.048, \mathrm{p}<0.05\right)$, being significantly more frequent in winter compared to the breeding season $\left(q=3.398\right.$, d.f. $\left.=_{¥, 3^{\prime}} p<0.05\right)$. The number of human disturbances did not change significantly among seasons ( $p>0.35)$.

During the day, the highest number of all disturbances $(62.5 \%, n=70)$ occurred between 1230 and 1530h. The peak number of natural disturbances $(25 \%)$ occurred at 1300h. The number of human disturbances reached a peak at $1130 \mathrm{~h}$ and remained constant for the rest of the day (Figure 4).

The three categories of reaction to disturbance of the sea lions (detection, alarmed, harassed) were generated in almost equal proportions when considering natural disturbances. Human disturbances generated detection in half of the cases, while $32 \%$ of these disturbances harassed the sea lions. The unknown sources of disturbance harassed the sea lions in a half of the cases (Table 1). The number of disturbances by category of reaction did not change significantly between seasons $(p>0.13)$; nevertheless, an increase in the number of disturbances that harassed the sea lions was observed from the breeding season to winter (Figure 3c).

The time for full recovery after all forms of disturbance ceased was between 0 to $10 \mathrm{~min}$ in $60 \%$ of the cases. However, when the disturbance caused a harassment reaction, the time it took animals to rehaul was between 0 to $210 \mathrm{~min}$. Only $10 \%$ of the disturbances $(n=15) \mathrm{did}$ not lead to an observed recovery. These disturbances caused harassment to the sea lions, except for one that caused alarm.

Conditions of disturbance. Seven factors were extracted from the principal component analysis, which explained $74 \%$ of the total variation in the data. Using three factors (accounting for $47 \%$ of the variation), a threedimensional plot was obtained that separated the disturbances into five clusters. The original variables with greater correlation with Factor I were: month, tidal level, relative humidity, Beaufort number, total number of boats and the number of powerboats at 11-20m distance to shore.

Factor I generated three clusters. The first grouped the disturbances $(n=41)$ generated in summer (breeding season) and autumn (May-November) when both powerboats and males (adult and subadult) were present simultaneously in the area. This was the hottest period of the year $\left(30-42^{\circ} \mathrm{C}\right)$, as well as one of high relative humidity $(50 \%-80 \%)$, medium to high tidal levels and small wavelets $(0.15 \mathrm{~m})$ (Figure 5).

Table 1. Number of disturbances by source and by category of reaction by California sea lions observed between May 2000 and April 2001 at Los Islotes, Baja California Sur, Mexico.

\begin{tabular}{|c|c|c|c|c|c|}
\hline & SOURCE & DETECTION & ALARMED & HARASSED & TOTAL \\
\hline \multirow[t]{4}{*}{ Natural Disturbance } & $\begin{array}{l}\text { Adult and Subadult } \\
\text { Males }\end{array}$ & 14 & 19 & 22 & \\
\hline & Pups & 4 & 0 & 3 & \\
\hline & Noise of birds & 3 & 1 & 1 & \\
\hline & Total (\%) & $21(31)$ & $20(30)$ & $26(39)$ & $67(60)$ \\
\hline \multirow[t]{5}{*}{ Human Disturbance } & "Panga" type vessel & 6 & 3 & 6 & \\
\hline & Noise & 4 & 1 & 1 & \\
\hline & Swimmers and divers & 1 & 1 & 2 & \\
\hline & Other vessels & 3 & 0 & 0 & \\
\hline & Total (\%) & $14(50)$ & $5(18)$ & $9(32)$ & $28(25)$ \\
\hline Unknown Disturbance & Total $(\%)$ & $5(29)$ & $4(24)$ & $8(47)$ & $17(15)$ \\
\hline TOTAL & & & & & 112 \\
\hline
\end{tabular}




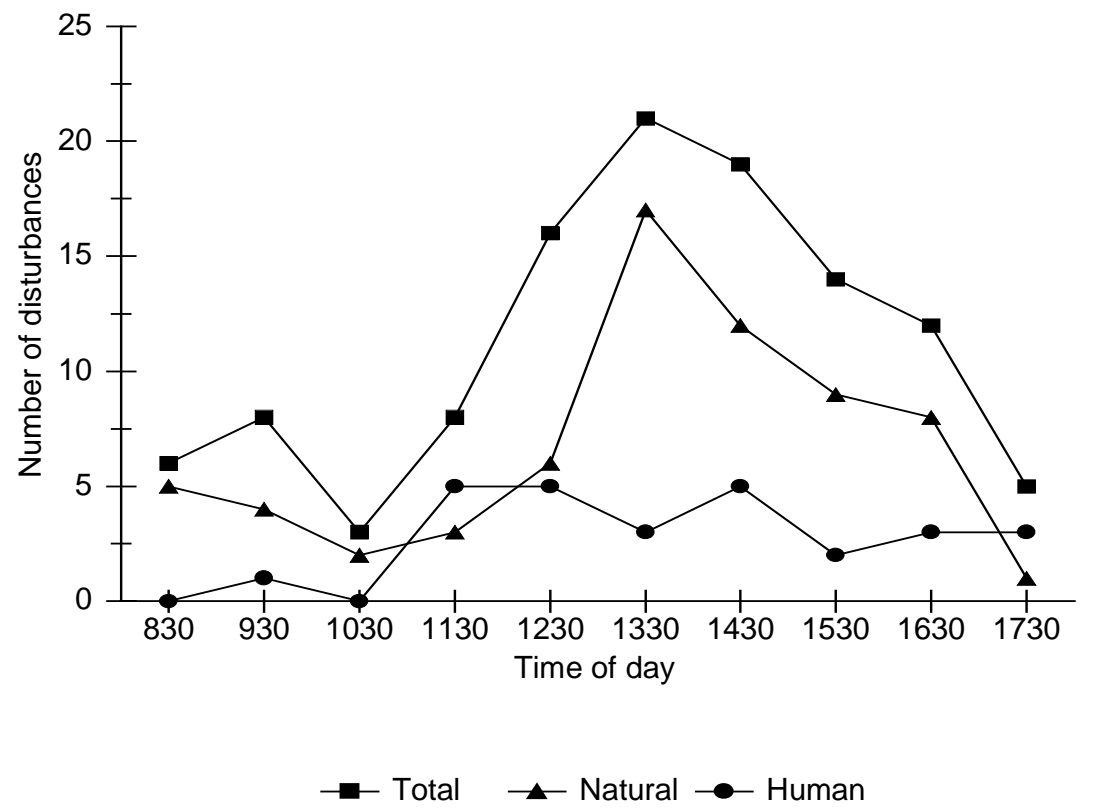

Figure 4. Number of disturbances observed at Los Islotes in relation to time of day between May 2000 and April 2001.

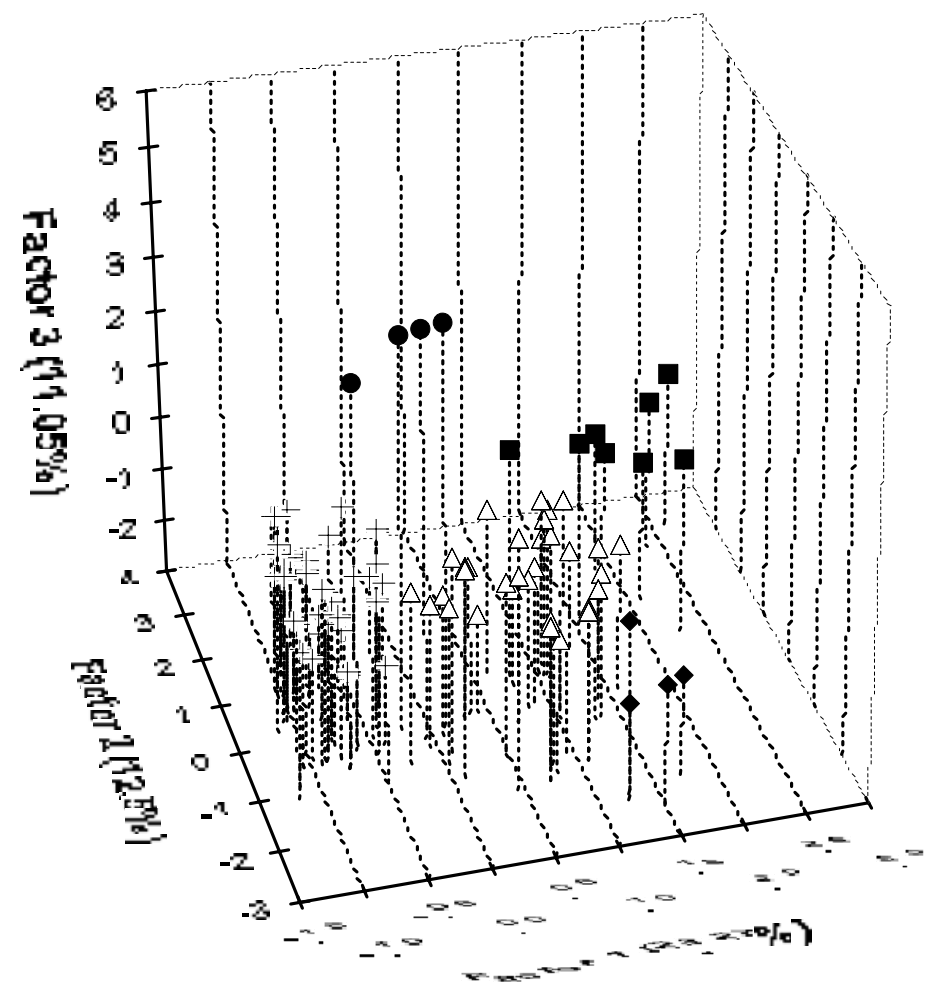

Figure 5. A three-dimensional plot of the principal-component factors calculated from the 16 natural and human variables for Los Islotes rookery. The disturbances formed five clusters: $(\triangle)$ Summer and Autumn (May-November); (+) Winter (January-April); $(\bullet)$ Autumn (October); $(\bullet)$ Summer with sailboats at 0-10 m; $(\bullet)$ Summer with sailboats at 11-20 m. 
The second cluster grouped the greatest number of disturbances $(n=57)$ of the year, which were generated in winter (January-April). These human and natural disturbances occurred when the greatest proportions of subadult males (10-78\%) were present in Zone A and when practically no boats were present at Los Islotes. This occurred under favorable weather conditions for sea lion haul-out, such as light breezes forming small waves $(0.08 \mathrm{~m})$ and low tide level. During this period, the lowest ranges of temperature $\left(17-32^{\circ} \mathrm{C}\right)$ and relative humidity (34\%-37\%) were recorded (Figure 5).

A third cluster grouped disturbances $(n=7)$ generated in autumn (October) when the greatest number of powerboats of the year were present simultaneously in the area (5-12 boats). This coincided with unfavorable weather conditions for sea lion haul-out, such as larger waves $(0.61 \mathrm{~m})$ and high tide level, as well as the highest recorded relative humidity of the year (70\%-81\%). These disturbances occurred even with the lowest proportion of subadult (2-26\%) and adult males (2-5\%) of the year were present in Zone A (Figure 5).

Two additional clusters were formed by Factor II $(n=3)$ and Factor III $(n=4)$ (Figure 5). These disturbances were generated during the summer under the conditions described above for that period, the difference being the presence of sailboats at $11-20 \mathrm{~m}$ and $0-10 \mathrm{~m}$ from shore, respectively, at the moment of disturbance.

\section{Discussion}

Population fluctuation during the year. The observations of the present study reflect the fact that the population dynamics at Los Islotes have remained the same over the last 20 years (Peterson and Bartholomew, 1967; Odell, 1975; Aurioles et al., 1983; Aurioles et al., 2003).

Suckling behavior. The curve for suckling observed during the reproductive period (May-August) also agrees with previous observations at Los Islotes by García-Aguilar and Aurioles-Gamboa (2003b). The highest intensity of suckling was recorded during June, and values decreased progressively as the season advanced. This study presents the first data on yearround suckling for sea lions in Los Islotes.

Tourism activity. The site most visited by tourists and where the greatest number of boats anchored throughout the year is also the area with the largest number of sea lions and the most important zone for reproduction (Zone A). The number of boats and people visiting the site and the use of the island area have increased significantly over recent years. Bircoll et al. (1994) reported 51 boats over 88 hours of observation in the months of September to November, while in the present study, 6 years later, 130 boats were observed during the same period but in only 60 hours of observation. This constitutes an increase of $273 \%$.
Disturbance. The fall and winter seasons seem to be the most susceptible to disturbance. The highest number of disturbances at Los Islotes was recorded in winter due to the activity of the large number of adult and subadult males present. The greatest number of harassment (sea lions going into the water) of the year was generated during this period. Disturbance caused by males is commonly observed in pinniped colonies, besides that resulting from the noise made by the pups at play and by the condition of the sea (Peterson and Bartholomew, 1967; Trillmich and Trillmich, 1984; Riedman, 1990). The sea state (large waves and high tide level), together with the large number of boats present at the same time at Los Islotes during the autumn season, were also factors which influenced sea lion behavior. The smallest number of disturbances recorded was during the reproductive period of the sea lions. Most of these, however, were caused by human activity, which implies that the perturbations on this period could be reduced. The number of anthropogenic disturbances occurred through the year of study without change.

The reproductive colonies of pinnipeds turn out to be the most affected by continuous disturbance (see review by Richardson et al., 1995) because the daily suckling patterns of the females are interrupted (Allen et al., 1984; Suryan and Harvey, 1999). Disturbance of the conduct of the animals occurred throughout the day at Los Islotes. The greatest frequency of natural disturbances occurred in the early afternoon (1300-1630 hours) which may be related to the diurnal pattern displayed by many species of otariids and phocids, where the number of animals increases as the daylight hours progress (Sullivan, 1980; Ainley et al., 1982; Allen et al., 1984; Yochem et al., 1987; Calambokidis et al., 1987; Allen-Miller, 1988; Beentjes, 1989; Erickson et al., 1989), generating a greater agitation amongst the individuals. The highest frequency of human disturbance was reached at 1130 hours and then remained constant. This was the time when the largest number of boats $(56 \%)$ was recorded at the site. It would thus be important to distribute the visits by boats throughout the day or to establish a schedule with intervals without boats, as well as to limit their number, as a means of regulating tourism. Reducing the number of boats to five in a specific area and moment would be the ideal option for regulation, as a collection of more than 5 boats generate disturbances even without the presence of males under unfavorable weather conditions according with our results.

Another priority for the regulation of tourism activity would be the distance to which boats, regardless of their size, may approach pinniped colonies. Disturbances by motorboats have been documented for harbor seal (Phoca vitulina) colonies elsewhere (Allen et al., 1984; Suryan and Harvey, 1999; Henry and Hammill, 2001). It has been observed that small boats such as canoes and kayaks cause stronger reactions by the animals than powerboats do, because of their close approach (Allen et al., 1984; Terhune, 1985; Suryan and Harvey, 1999; 
Henry and Hammill, 2001). The distance of the boats appears to be the only variable that significantly affects the behavior of the harbor seal in California (Allen et al., 1984). The main source of human disturbance all year round at Los Islotes was the "panga" due to their close approaches (some as close as $5 \mathrm{~m}$ ). Of the human disturbance, $71 \%$ were caused when the source was less than $20 \mathrm{~m}$ from the rookery.

The recording of disturbances of unknown origin was due, as in other studies, to the topographic characteristics of the area (Suryan and Harvey, 1999). Although the field of vision included all of the focal group (Zone A), the topography of the island did not permit seeing the source of disturbance coming from the adjacent Zone B. It is interesting to note that, in half of the cases, this type of disturbance generated harassment when the animals in the focal reacted instinctively to the disturbance coming from Zone B, stampeding into the sea.

The degree of tolerance towards noise and human presence varies between species, populations and even individuals (Terhune and Almon, 1983 in Suryan and Harvey, 1999; Riedman, 1990; Richardson et al., 1995). Animals that live in areas commonly visited by people show greater tolerance than those living in zones with less disturbance (Peterson and Bartholomew, 1967). The sea lions of Los Islotes, which have received regular visits by tourists for about 30 years (López-Espinosa, 2002), show great tolerance for the presence of humans, compared to the harbor seal (Phoca vitulina) (Allen et al., 1984; Suryan and Harvey, 1999), as well as individuals of the same species that inhabit coastal areas of California (Peterson and Bartholomew, 1967) and in the Gulf of California (authors pers. obs.). At Los Islotes colony, the sea lions do not react at all to the activity of boats further than $50 \mathrm{~m}$ away.

It has been shown, however, that although the animals do not manifest change in behavior in relation to the presence of humans, they may be showing physiological changes (MacArthur et al., 1982) and stress (Creel et al., 2002). The long-term effects of disturbance on natural populations are difficult to evaluate (Richardson et al., 1995; Findlay, 1997; Suryan and Harvey, 1999). Although California sea lions exhibit a certain degree of tolerance to the presence of tourism at Los Islotes, the level of stress the presence of humans may be generating in these animals is unknown.

Despite the establishment of guidelines regulating tourism activity at Los Islotes (SEMARNAT, 2000), the observations carried out in this study reveal that as of 2001 tourism activity has continued without order and with no restrictions, generating disturbance to the California sea lion, both daily and seasonally, including the breeding season of the animals. Tourism activity development in Bahía de La Paz has increased notably over the last decade (López-Espinosa, 2002) and greater tourism development is anticipated for the city of La Paz. An uncoordinated increase in tourism at the rookery could, over the long term, alter the reproductive behavior and rearing of the young as well as the health of the animals. Of primary concern is the development of regulations for tourism activity in the vicinity of the rookery to protect the health of the colony, of the habitat and the scenic value of Los Islotes, guaranteeing at the same time the continuation of an important economic activity for the region.

\section{Acknowledgements}

This study was funded by the Nature Conservancy, International Conservation Program through the organization Conservación del Territorio Insular Mexicano (ISLA A.C.). The Instituto Nacional de Ecología (INE) provided permits for field work (DOO.02.-) through the regional office in Baja California Sur, Área de Protección de Flora y Fauna "Islas del Golfo de California". The Programa Institucional de Formación de Investigadores (PIFI-IPN) and the Consejo Nacional de Ciencia y Tecnología (CONACYT) for the scholarships assigned for postgraduated studies. We thank Norman Silverberg and Nélio Barros for reviewing the English of the manuscript, and two anonymous reviewers for their valuable suggestions on an earlier version of the manuscript. The first author is grateful to Sarah G. Allen for her comments and the many papers she sent. We wish to thank all the persons at Centro Interdisciplinario de Ciencias Marinas, Instituto Politécnico Nacional (CICIMAR-IPN) who made the field activities possible.

\section{References}

Ainley, D.G.,Huber, H.R. And Bailey, K.M. (1982) Population fluctuations of California sea lions and the Pacific whiting fishery off Central California. Fishery Bulletin 80: 253-258.

Allen, S.G., Ainley, D.G., Page, G.W. And Ribic, C.A. (1984) The effect of disturbance on harbor seal haul out patterns at Bolinas Lagoon, California. Fishery Bulletin 82: 493-500.

Allen, S.G. (1991) Harbor seal, habitat restoration at Strawberry Spit, San Francisco Bay. Point Reyes Bird Observatory, California, Final Report, 45 p.

Allen-Miller, S. (1988) Movement and activity patterns of harbor seals at the Point Reyes peninsula, California. MSc Thesis, University of California, Berkeley, $70 \mathrm{p}$.

Altmann, J. (1974) Observational study of behavior: sampling methods. Behaviour 49: 227-265.

Aurioles-Gamboa, D., Sinsel, F., Fox, C., Alvarado, E. and Maravilla, O. (1983) Winter migration of subadult male California sea lions (Zalophus californianus) in the southern part of Baja California. Journal of Mammalogy 64:513-518.

Aurioles-GamboA, D. And Zavala-GonZÁlez, A. (1994) Algunos factores ecológicos que determinan la distribución y abundancia del lobo marino Zalophus californianus, en el Golfo de California. Ciencias Marinas 20:535-553. 
Aurioles-Gamboa D., Godinez, C., Duran, M.E., García, F.J., Hernández, C.J., Luque, S., Miller, P.Ellis, S. (Eds) (1999) Conservación, análisis y manejo planificado sobre los pinnípedos de México y análisis de la viabilidad de la población y del hábitat para el lobo marino de California (Zalophus californianus californianus). Inform UICN/SSC, Conservation Breeding Specialist Group, Apple Valley, Minnesota, $65 \mathrm{p}$.

Aurioles-Gamboa, D., García-Rodríguez, F., Ramírez-RodrígueZ, M. AND HERNÁNDEZ-CAMACHO, C. (2003) Interaction between the California sea lion and the artisanal fishery in La Paz Bay, Gulf of California, Mexico. Ciencias Marinas 29:357-370.

Barnes- Svarney, P. (Ed.) (1995) Science desk reference, Macmillan, New York, 668 p.

Bartholomew, G.A. (1967) Seal and sea lion populations of the California islands. Pages 229-244 in R.N. Philbrick (Ed) Proceedings of the symposium on the biology of the Channel Islands. Santa Barbara Botanic Garden, California.

BEENTJES, M.P. (1989) Haul out patterns, site fidelity and activity budgets of male Hooker's sea lions (Phocarctos hookeri) on the New Zealand mainland. Marine Mammal Science 5:281-297.

Bejder, L., Dawson, S.M. and Harraway, J.A. (1999) Responses by Hector's dolphins to boats and swimmers in Porpoise Bay, New Zeland. Marine Mammal Science 15: 738-750.

Bircoll, M., CABOt, C., Rusillo, C. and Tano, D. (1994) A study of California sea lion (Zalophus californianus) pup suckling behavior on Los Islotes and the economic value of Los Islotes for the city of La Paz. Final Report, School for Field Studies, Center of Marine Mammals Studies, San Carlos, México, 22 p.

Brasseur S., Creunels, J., Werf, B. And Reijnders, P. (1996) Deprivation indicates necessity for haul-out in Harbor seals. Marine Mammal Science 12: 619-624.

Calambokidis, J., Taylor, B.L., Carter, S.D., Steiger, G.H., DAwson, P.K. AND ANTRIM, L.D. (1987) Distribution and haul out behavior of harbor seals in Glacier Bay, Alaska. Canadian Journal of Zoology 65: 1391-1396.

Constantine, R. (2001) Increased avoidance of swimmers by wild bottlenose dolphins (Tursiops truncatus) due to long-term exposure to swim-with-dolphin tourism. Marine Mammal Science 17: 689-702.

Creel, S., Fox, J.E., Hardy, A., Sands, J., Garrott, B. and Peterson, R.O. (2002) Snowmobile activity and glucocorticoid stress responses in wolves and elk. Conservation Biology 16: 809-814.

Engelhard, G.H., BaArspul, A.N.J., Broekman, M., Creuwels, J.C.S. AND REIJNDERS, P.J.H. (2002) Human disturbance, nursing behaviour and lactational pup growth in a declining southern elephant seal (Mirounga leonina) population. Canadian Journal of Zoology 80: 1876-1886.

ERICKSON, A.W., BledSOE, L.J. AND HANSON, M.B. (1989) Bootstrap correction for diurnal activity cycle in census data for Antarctic seals. Marine Mammal Science 5: 29-56.

FindLAY, K. (1997) A review of the effects of tourism activities on cetaceans. Working paper submitted to the International Whaling Commission Scientific committee $49^{\text {th }}$ Annual Meeting, SC/49/029, Monaco. 23 p.

García-Aguilar, M.C. and Aurioles-Gamboa, D. (2003a)
Breeding season of the California sea lion (Zalophus californianus) in the Gulf of California, Mexico. Aquatic Mammals 29: 67-76.

García-Aguilar, M.C. and Aurioles-Gamboa, D. (2003b) Maternal care in the California sea lion at Los Islotes, Gulf of California, Mexico. Ciencias Marinas 29: 573-583.

HenRY, E. And Hammill, M.O. (2001) Impact of small boats on the haulout activity of harbour seals (Phoca vitulina) in Métis Bay, Saint Lawrence Estuary, Québec, Canada. Aquatic Mammals 27: 140-148.

Hernández-CAMAcho, C.J. (2001) Tabla de vida del lobo marino de California Zalophus californianus californianus en la lobera Los Islotes, Baja California Sur, México. MSc. Thesis, CICIMARIPN, La Paz, Baja California Sur, Mexico. 63 p.

Hort, E. (2001) Whale Watching 2001: Woldwide tourism numbers, expenditures, and expanding socioeconomic benefits. International Fund for Animal Welfare, Yarmouth Port, MA, USA, $158 \mathrm{p}$.

Jay, C.V., Olson, T.L., GARner, G.W. And Ballachey, B.E. (1998) Response of Pacific walruses to disturbances from capture and handling activities at a haul-out in Bristol Bay, Alaska. Marine Mammal Science 14: 819-828.

Johnson, W.M. And Lavigne, D.M. (1999) Mass tourism and the Mediterranean monk seal. The role of mass tourism in the decline and possible future extinction of Europe's most endangered marine mammal, Monachus monachus. The Monachus Guardian 2: 62-81.

Karamanlidis, A.A. (2000) Monitoring human and Mediterranean monk seal actvity in The National Marine Park of Alonnissos and Northern Sporades, Greece. The Monachus Guardian 3: 1-10

KENYON, K.W. (1972) Man versus the monk seal. Journal of Mammalogy 53: 687-696.

Kerley, L.L., Goodrich, J.M., Miguelle, D.G., Smirnov, E.N., Quigley, H.B. AND HoRNOCKER, M.G. (2002) Effects of roads and human disturbance on Amur tigers. Conservation Biology 16: 97-108

Le Boeuf, B.J., Aurioles-Gamboa, D.Condit, R., Fox, C., Gisiner, R., Romero, R. AND Sinsel, F. (1983) Size and distribution of the California sea lion population in México. Proceedings of the California Academy of Sciences 43: 77-85.

López-EsPINOSA, R. (2002) Evaluating ecotourism in natural protected area of La Paz, Baja California Sur, Mexico: ecotourism or nature-based tourism?. Biodiversity and Conservation 11: 1539-1550.

MacArthur, R.A., Geist, V. And Johnston, R.H. (1982) Cardiac and behavioral responses of mountain sheep to human disturbace. Journal of Wildlife Management 46: 351-358.

Malcom, C. And Lochbaum, E. (Eds) (1999) Human-Marine Mammal Interaction Workshop Proceedings. University of Victoria, Department of Fisheries and Oceans, Nanaimo, British Columbia, $25 \mathrm{p}$.

ODELL, D.K. (1975) Breeding biology of the California sea lion Zalophus californianus. Rapport et Proces-Verbaux des Réunions Conseil International pour l'Exploration de la Mer 169: 374-378.

Paulbitsky, P.A. (1975) The seals of Strawberry Spit. Discovery 28(4): 12-15. 
Peterson, R.S. AND BARTHOLOMEW, G.A. (1967) The natural history and behavior of the California sea lion. The American Society of Mammalogists, Special Publication No.1., Stillwater, Oklahoma, $79 \mathrm{p}$.

Richardson, W.J., Greene, C.R., Macme, C.I. And Thomson, D.H. (1995) Marine mammals and noise, Academic Press, San Diego, California, $576 \mathrm{p}$.

Riedman, M. (1990) The Pinnipeds, Seals, Sea Lions and Walruses. University of California Press, Berkeley, California, 439 p.

SEMARNAP. (2000) Proyecto para la conservación, manejo y aprovechamiento sustenatable de los pinnípedos en México. Instituto Nacional de Ecología, Distrito Federal, México, 91 p.

SEMARNAT. (2000) Programa de manejo Complejo Insular del Espíritu Santo. Comisión Nacional de Áreas Naturales Protegidas, Distrito Federal, Mexico, 194 p.

StATSOFt, Inc. (2001) STATISTICA for Widows. Version 6. Stat Soft Inc., Tulsa, Oklahoma.

SulLivan, R.M. (1980) Seasonal occurrence and haul out use in pinnipeds along Humboldt County, California, Journal of Mammalogy 61: 754-760.

SURYAN, R.M. AND HARVEY, J.T. (1999) Variability in reactions of Pacific harbor seals, Phoca vitulina richardsi, to disturbance. Fishery Bulletin 97: 332-229.

Terhune, J.M. And Almon, M. (1983) Variability of harbour seal numbers on haul out sites. Aquatic Mammals 10: 71-78.

Trillmich, F. AND Trillmich, K. (1984) The mating systems of pinnipeds and marine iguanas: convergent evolution of polygyny. Biological Journal of the Linnean Society 21: 209-216.

Yochem, P.K., Stewart, B.S., DeLong, R.L. And DeMaster, D.P. (1987) Diel haul out patterns and site fidelity of harbor seals (Phoca vitulina richardsi) on San Miguel island, California, in autumn. Marine Mammal Science 3: 323-332.

ZAR, J.H. (1999) Biostatistical analysis. $4^{\text {th }}$ ed. Prentice-Hall, New Jersey, 663 p.

Zavala-GonZÁLEZ, A. AND MellinK, E. (1997) Entanglement of California sea lions, Zalophus californianus californianus, in fishing gear in the central-northern part of the Gulf of California, Mexico. Fishery Bulletin 95:180-184. 
